\title{
Photoproduction of iodine with nanoparticulate semiconductors and insulators
}

\author{
Chockalingam Karunakaran*, Premkumar Anilkumar and Paramasivan Gomathisankar
}

\begin{abstract}
The crystal structures of different forms of $\mathrm{TiO}_{2}$ and those of $\mathrm{BaTiO}_{3}, \mathrm{ZnO}, \mathrm{SnO}_{2}, \mathrm{WO}_{3}, \mathrm{CuO}, \mathrm{Fe}_{2} \mathrm{O}_{3}, \mathrm{Fe}_{3} \mathrm{O}_{4}, \mathrm{ZrO}_{2}$ and $\mathrm{Al}_{2} \mathrm{O}_{3}$ nanoparticles have been deduced by powder $\mathrm{X}$-ray diffraction. Their optical edges have been obtained by UV-visible diffuse reflectance spectra. The photocatalytic activities of these oxides and also those of $\mathrm{SiO}_{2}$ and $\mathrm{SiO}_{2}$ porous to oxidize iodide ion have been determined and compared. The relationships between the photocatalytic activities of the studied oxides and the illumination time, wavelength of illumination, concentration of iodide ion, airflow rate, photon flux, pH, etc., have been obtained. Use of acetonitrile as medium favors the photogeneration of iodine.
\end{abstract}

\section{Background}

Nanoparticles exhibit physical properties distinctively different from that of bulk. They possess a large fraction of surface atoms or ions or molecules in unit volume. The very large surface area provides a huge surface energy. Further, the electronic structures of semiconductor nanocrystals differ from those of bulk materials. Band gap-illumination of semiconductor results in formation of electron-hole pairs; electron in the conduction band (CB) and hole in the valence band (VB) [1]. While most of the electron-hole pairs recombine, some of the charge carriers diffuse to the crystal surface and react with the adsorbed electron donors and acceptors leading to photocatalysis. Here we compare the photocatalytic efficiencies of nanocrystalline semiconductors. Iodide ion is the test substrate taken up for the study. Production of energy bearing chemicals through thermodynamically uphill reactions is the objective of solar energy conversion and storage and iodide ion-oxidation is such a reaction $\left(\Delta G^{\circ}=+51.6 \mathrm{~kJ} \mathrm{~mol}^{-1}\right)$. In addition, it is well known that degradation of organic molecules involve photogenerated reactive oxygen species (ROS) and the major active oxidizing species is hydroxyl radical [2]. The capacity to photogenerate hydroxyl radical is also taken as a measure of the photocatalytic activity of photocatalyst [3]. More importantly, the photocatalytic mineralization of organics is complicated by the

\footnotetext{
* Correspondence: karunakaranc@rediffmail.com

Department of Chemistry, Annamalai University, Annamalainagar 608002, Tamilnadu, India
}

formation of a number of stable intermediates. But the iodide ion oxidation is a simple electron transfer process [4-7]. Further, unlike iodide ion the organic molecules such as phenols and dyes may have chemical affinity to the oxide surface and enter into some sort of bond formation with the oxides. These factors led to the selection of iodide ion as the test substrate for this investigation. The present photocatalytic results on iodide ion oxidation show that some of the nanocrystalline semiconductors are less efficient photocatalysts than insulators such as $\mathrm{Al}_{2} \mathrm{O}_{3}$ and $\mathrm{SiO}_{2}$. Recently, we have reported photodegradation of carboxylic acids on $\mathrm{Al}_{2} \mathrm{O}_{3}$ and $\mathrm{SiO}_{2}$ nanoparticles [8].

\section{Results and Discussion}

\subsection{Crystal structure}

The X-ray diffraction (XRD) pattern of $\mathrm{TiO}_{2}$ anatase, shown in Figure 1, confirms the anatase phase of the sample. The recorded XRD matches with the JCPDS pattern of $\mathrm{TiO}_{2}$ anatase (89-4921, body centered tetragonal, a 3.8101 $\AA, b 3.8101, c$ 9.3632, $\alpha 90^{\circ}, \beta 90^{\circ}, \gamma$ $90^{\circ}$ ) and the rutile lines (JCPDS 89-4202) are absent. The presence of rutile phase in the rutile $\mathrm{TiO}_{2}$ is evident from the observed XRD of rutile $\mathrm{TiO}_{2}$. While the anatase peaks (JCPDS 89-4921) are not seen, the displayed XRD of the rutile sample matches satisfactorily with the JCPDS pattern of rutile $\mathrm{TiO}_{2}$ (89-4202). The cell parameters are: primitive tetragonal, $a 4.627 \AA, b$ $4.627 \AA, c 2.9757 \AA, \alpha 90^{\circ}, \beta 90^{\circ}, \gamma 90^{\circ}$. The recorded XRD of $\mathrm{TiO}_{2}$ P25 Degussa confirms the presence of 


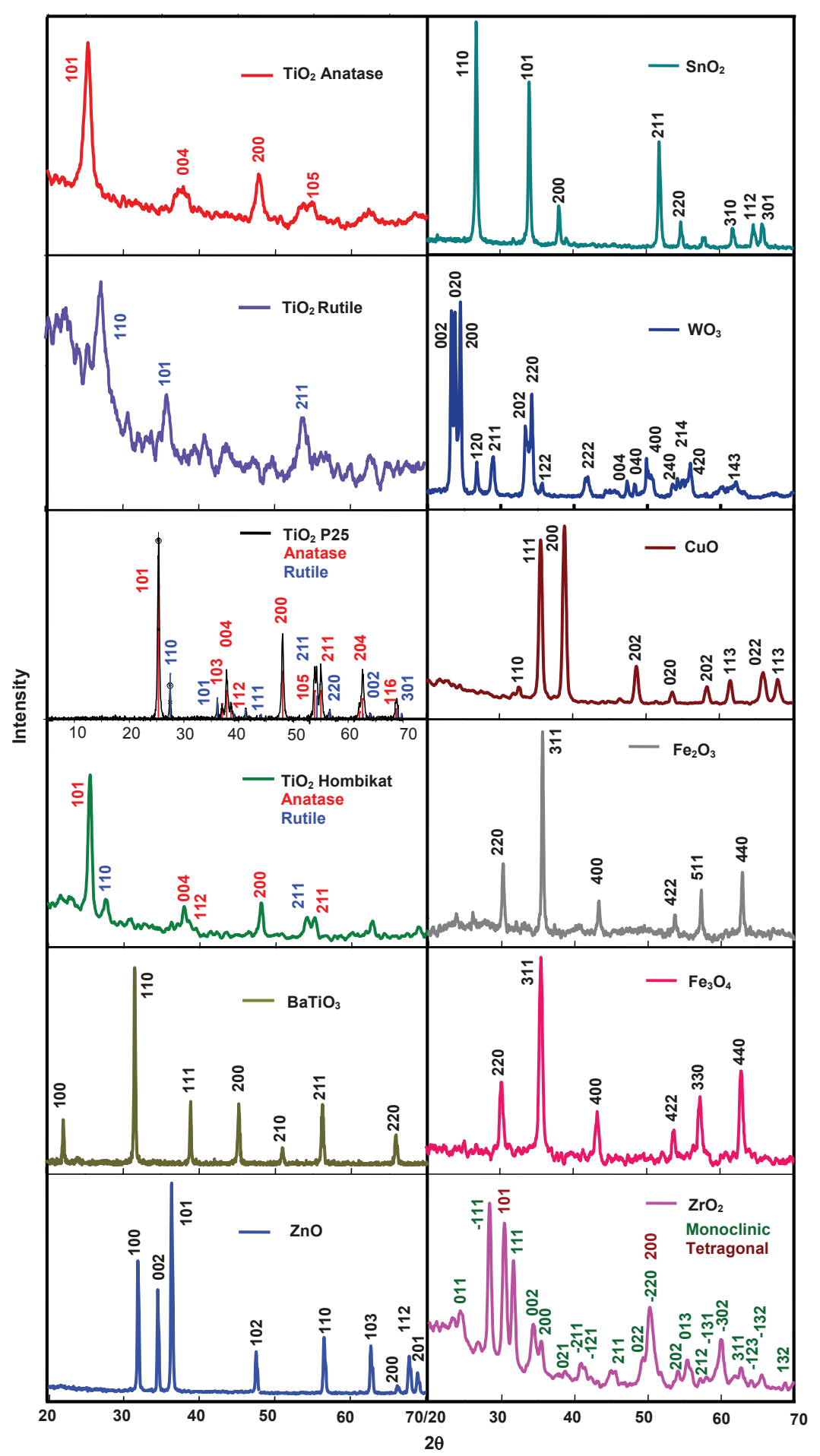

Figure 1 Powder XRD patterns of nanocrystalline semiconductors. 
anatase and rutile phases in the sample. The JCPDS patterns of anatase (00-021-1272 $(*))$ and rutile (01-089$0553(\mathrm{C})$ ) are observed in the XRD of $\mathrm{P} 25 \mathrm{TiO}_{2}$. The cell parameters are: anatase: body centered tetragonal, $a$ $3.7852 \AA, b 3.7852, c 9.5139, \alpha 90^{\circ}, \beta 90^{\circ}, \gamma 90^{\circ}$ and rutile: primitive tetragonal, $a 4.5925 \AA, b 4.5925 \AA, c$ $2.9560 \AA, \alpha 90^{\circ}, \beta 90^{\circ}, \gamma 90^{\circ}$. The phase percentages have been obtained from the integrated intensity of the peaks at $2 \theta$ value of $25.3^{\circ}$ (101-plane) for anatase and $27.4^{\circ}$ (110-plane) for rutile. The percentage of anatase is given by $A(\%)=100 /\left[1+1.265\left(I_{\mathrm{R}} / I_{\mathrm{A}}\right)\right]$, where $I_{\mathrm{A}}$ and $I_{\mathrm{R}}$ are the intensities of anatase and rutile peaks, respectively. The phase composition determined by the XRD method is $81 \%$ anatase and $19 \%$ rutile, which is in agreement with the literature. The XRD of $\mathrm{TiO}_{2} \mathrm{Hombi}$ kat shows the presence of anatase and rutile phases in the crystal; peak fitting of the XRD conforms to the combined XRD pattern of $\mathrm{TiO}_{2}$ anatase (JCPDS 894921) and rutile (JCPDS 89-4202). The crystal parameters are: anatase: body centered tetragonal, $a 3.7792$ $\AA, b 3.7792 \AA, c 9.4910 \AA, \alpha 90^{\circ}, \beta 90^{\circ}, \gamma 90^{\circ}$; rutile: primitive tetragonal, $a 4.627 \AA$, $b 4.627 \AA, c 2.9757 \AA$, $\alpha$ $90^{\circ}, \beta 90^{\circ}, \gamma 90^{\circ}$. The percentages of anatase and rutile phases present in the sample, obtained from the XRD data, are 69 and 31, respectively. The powder XRD of $\mathrm{BaTiO}_{3}$ employed confirms its crystal structure as primitive cubic. It is in total agreement with JCPDS 89-2475. The crystal constants are: $a 4.0085 \AA, b 4.0085 \AA$, $c$ $4.0085 \AA, \alpha 90^{\circ}, \beta 90^{\circ}, \gamma 90^{\circ}$.

The recorded diffractogram of $\mathrm{ZnO}$ confirms its crystal structure. The peak fitting is highly satisfactory (JCPDS 89-7102) and the deduced crystal parameters are: primitive hexagonal, $a 3.2526 \AA, b 3.2526 \AA, c$ $5.1888 \AA, \alpha 90^{\circ}, \beta 90^{\circ}, \gamma 120^{\circ}$. The diffraction pattern of $\mathrm{SnO}_{2}$ is in accordance with its structure. It is in complete agreement with that of JCPDS 88-0287. The cell constants are: primitive tetragonal, $a 4.7355 \AA, b 4.7355$ $\AA, c 3.1703 \AA$, $\alpha 90^{\circ}, \beta 90^{\circ}, \gamma 90^{\circ}$. The $\mathrm{WO}_{3}$ crystals provide an XRD pattern that belongs to primitive monoclinic system (JCPDS 89-4476). The crystal constants are: $a 7.3291 \AA, b 7.5006 \AA, c 7.6718 \AA, \alpha 90^{\circ}, \beta 88.18 \pm$ $2.89^{\circ}, \gamma 90^{\circ}$. The XRD pattern of $\mathrm{CuO}$ matches with JCPDS 89-2529 pattern and confirms the crystal structure as end centered monoclinic with crystal constants as: $a 4.6977 \AA, b 3.4193 \AA, c 5.1285 \AA, \alpha 90^{\circ}, \beta 81.20 \pm$ $3.76^{\circ}, \gamma 90^{\circ}$. The recorded XRD pattern of $\mathrm{Fe}_{2} \mathrm{O}_{3}$ shows the oxide as maghemite $\left(\gamma-\mathrm{Fe}_{2} \mathrm{O}_{3}\right)$. The XRD is in total agreement with JCPDS 39-1346 and the crystals belong to cubic system with unit cell length as $8.3515 \AA$. The $\mathrm{Fe}_{3} \mathrm{O}_{4}$ used is of face centered cubic system. The recorded XRD pattern is in agreement with JCPDS 894319. The crystal parameters are: $a 8.3381 \AA$, $b 8.3381$ $\AA, c 8.3381 \AA, \alpha 90^{\circ}, \beta 90^{\circ}, \gamma 90^{\circ}$.
The XRD peaks of zirconia show the oxide as a blend of monoclinic and tetragonal forms. The combined JCPDS patterns of monoclinic $\mathrm{ZrO}_{2}$ (24-1165) and tetragonal $\mathrm{ZrO}_{2}$ (81-1546) match with the observed XRD. The crystal parameters are: primitive monoclinic (baddeleyite), $a 5.145 \AA$, $b 5.207 \AA$, $c 5.311 \AA, \alpha 90^{\circ}, \beta$ $99.23^{\circ}, \gamma 90^{\circ}$ and primitive tetragonal, $a 3.622 \AA, b 3.622$ $\AA, c 5.205 \AA, \alpha 90^{\circ}, \beta 99.23^{\circ}, \gamma 90^{\circ}$. The volume fractions of the tetragonal $\left(\chi_{t}\right)$ and monoclinic $\left(\chi_{m}\right)$ phases are 0.34 and 0.66 , respectively. They have been deduced from the integrated peak intensities of the $(101)_{t}$ plane of the tetragonal phase $\left(I_{t}\right)$ and the $(111)_{m}$ and $(-111)_{m}$ planes of the monoclinic phase $\left(I_{m}\right)$ as follows: $\chi_{t}=I_{t}$ (101) $/\left[I_{t}(101)+I_{m}(111)+I_{m}(-111)\right]$ and $\chi_{m}=1-\chi_{t}$. The XRD of $\mathrm{Al}_{2} \mathrm{O}_{3}$ is displayed in Figure 2. It shows the existence of gamma $(\gamma)$ and delta $(\delta)$ phases. The recorded diffraction pattern matches with the combined JCPDS patterns of $\gamma-\mathrm{Al}_{2} \mathrm{O}_{3}$ (JCPDS 10-0425) and $\delta$ $\mathrm{Al}_{2} \mathrm{O}_{3}$ (JCPDS 00-016-0394). The crystal characteristics are: $\gamma-\mathrm{Al}_{2} \mathrm{O}_{3}$ : cubic, $a 7.9000 \AA, b 7.9000 \AA, c 7.9000 \AA$, $\alpha 90^{\circ}, \beta 90^{\circ}, \gamma 90^{\circ} ; \delta-\mathrm{Al}_{2} \mathrm{O}_{3}$ : tetragonal, $a 7.9430 \AA, b$ $7.9430 \AA, c 23.5000 \AA, \alpha 90^{\circ}, \beta 90^{\circ}, \gamma 90^{\circ}$. The percentages of $\gamma$ - and $\delta$-phases are 65.2 and 34.8, respectively.

The average sizes of the different nanocrystals $(D)$ have been obtained from the half-width of the full maxima (HWFM) of the most intense peaks of the samples using the Scherrer formula $D=0.9 \lambda / \beta \cos \theta$, where $\lambda$ is the $\mathrm{X}$-ray wavelength, $\theta$ is the Bragg angle and $\beta$ is the corrected line broadening. The XRD peaks used to calculate the average crystallite sizes are those of 101, 110, $101,101,110,101,110,200,200,311,311,-111$ and 400 planes of $\mathrm{TiO}_{2}$ anatase, $\mathrm{TiO}_{2}$ rutile, $\mathrm{TiO}_{2} \mathrm{P} 25, \mathrm{TiO}_{2}$ Hombikat, $\mathrm{BaTiO}_{3}, \mathrm{ZnO}, \mathrm{SnO}_{2}, \mathrm{WO}_{3}, \mathrm{CuO}, \mathrm{Fe}_{2} \mathrm{O}_{3}$, $\mathrm{Fe}_{3} \mathrm{O}_{4}, \mathrm{ZrO}_{2}$, and $\mathrm{Al}_{2} \mathrm{O}_{3}$, respectively. The specific surface areas of the nanoparticles have been deduced using the relationship $S=6 / d \rho$, where $S$ is the specific surface

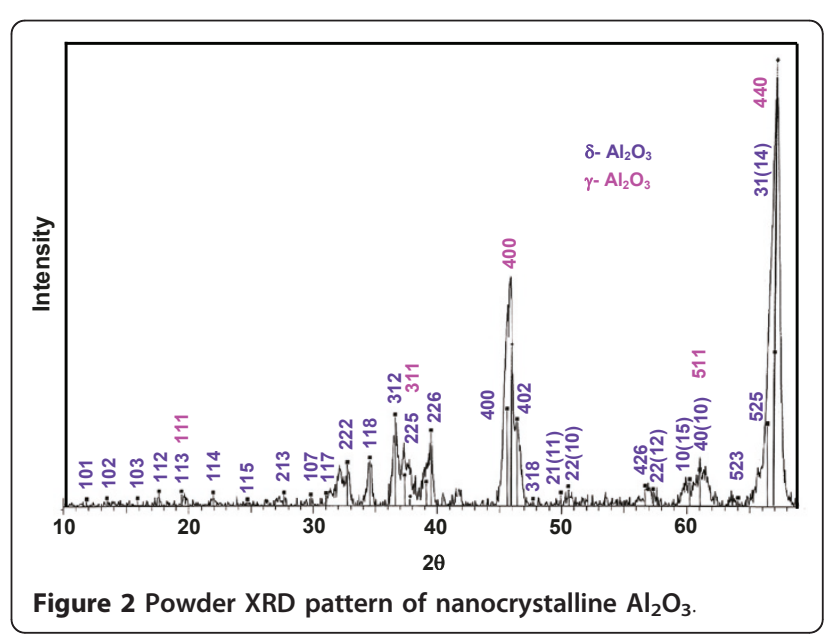


area, $d$ is the mean particle size and $\rho$ is the material density. Table 1 presents the results. The displayed particle sizes and surface areas of amorphous $\mathrm{SiO}_{2}$ are those provided by Sigma Aldrich.

\subsection{Optical edge}

The diffuse reflectance spectra (DRS) of the employed oxides are shown in Figure 3. The reflectance data are presented as $F(R)$ value, obtained by the application of Kubelka-Munk (K-M) algorithm $\left[F(R)=\left(1-R^{2}\right) / 2 R\right]$, where $R$ is the reflectance. The DRS clearly show that $\mathrm{SiO}_{2}, \mathrm{Al}_{2} \mathrm{O}_{3}$ and $\mathrm{ZrO}_{2}$ do not absorb UVA light. Figure 3 also displays the band gap excitation of $\mathrm{TiO}_{2}$ anatase, $\mathrm{TiO}_{2} \mathrm{P} 25, \mathrm{TiO}_{2}$ Hombikat, $\mathrm{TiO}_{2}$ rutile, $\mathrm{BaTiO}_{3}, \mathrm{ZnO}$ and $\mathrm{SnO}_{2}$ under UVA radiation. The DRS further reveals that blue light is capable of effecting band gap excitation of $\mathrm{WO}_{3}$. In addition, the DRS of $\mathrm{Fe}_{2} \mathrm{O}_{3}$ displays the commencement of light absorption at about $600 \mathrm{~nm}$ itself. Also, the DRS of $\mathrm{CuO}$ shows that the oxide is susceptible to photoexcitation by the entire spectrum of visible light. The DRS of $\mathrm{Fe}_{3} \mathrm{O}_{4}$ does not show any significant variation in the measured reflectance with visible and UVA light. This is because of its reported band gap of about $0.1 \mathrm{eV}$ [9]. The displayed K$\mathrm{M}$ plots are in total agreement with the expected band gaps of the studied oxides [9]. The band gap of $\mathrm{ZrO}_{2}$ is very wide (about $5 \mathrm{eV}$ ) and $\mathrm{Al}_{2} \mathrm{O}_{3}$ and $\mathrm{SiO}_{2}$ are

Table 1 Size $(D)$ and surface area $(S)$ of the oxides with rates of iodide ion-photooxidation*

\begin{tabular}{|c|c|c|c|c|}
\hline \multirow[t]{2}{*}{ Oxide } & \multirow[t]{2}{*}{$\begin{array}{l}D \\
(\mathrm{~nm})\end{array}$} & \multirow{2}{*}{$\begin{array}{l}S \\
\left(\mathrm{~m}^{2} \mathrm{~g}^{-}\right. \\
\left.{ }^{1}\right)\end{array}$} & \multicolumn{2}{|c|}{$\begin{array}{l}\text { lodine-formation } \\
\left(\mathrm{nM} \mathrm{s}^{-1}\right)\end{array}$} \\
\hline & & & Water & Acetonitrile \\
\hline $\mathrm{TiO}_{2}$ (anatase) & 9 & 165 & 216 & 361 \\
\hline $\mathrm{TiO}_{2}$ P25 (anatase:rutile::81:19) & 23 & 68 & 39 & 257 \\
\hline $\begin{array}{l}\mathrm{TiO}_{2} \text { Hombikat (anatase: } \\
\text { rutile::69:31) }\end{array}$ & 18 & 87 & 63 & 232 \\
\hline $\mathrm{TiO}_{2}$ (rutile) & 12 & 123 & 2.5 & 24 \\
\hline $\mathrm{BaTiO}_{3}$ & 41 & 24 & 5.4 & 27 \\
\hline ZnO (wurtzite) & 32 & 33 & 6.9 & 93 \\
\hline $\mathrm{SnO}_{2}$ & 27 & 31 & 2.4 & 21 \\
\hline $\mathrm{WO}_{3}$ & 23 & 39 & 1.6 & 61 \\
\hline $\mathrm{CuO}$ & 28 & 33 & 0.4 & 23 \\
\hline $\mathrm{Fe}_{2} \mathrm{O}_{3}$ & 39 & 32 & 1.7 & 24 \\
\hline $\mathrm{Fe}_{3} \mathrm{O}_{4}$ & 32 & 36 & 0.8 & 21 \\
\hline $\mathrm{ZrO}_{2}$ & 25 & 42 & 1.1 & 20 \\
\hline $\mathrm{Al}_{2} \mathrm{O}_{3}(\gamma: \delta:: 65: 35)$ & 11 & 148 & 8.9 & 32 \\
\hline $\mathrm{SiO}_{2}$ & 15 & $\begin{array}{l}160 \pm \\
20\end{array}$ & 12 & 44 \\
\hline $\mathrm{SiO}_{2}$ (porous) & 10 & $\begin{array}{l}640 \pm \\
50\end{array}$ & 6.5 & 27 \\
\hline
\end{tabular}

*0.020 g oxide loading, $0.050 \mathrm{M}$ iodide solution $(25 \mathrm{~mL}), 7.8 \mathrm{~mL} \mathrm{~s}^{-1}$ airflow, $365 \mathrm{~nm}, 25.2 \mu$ Einstein $\mathrm{L}^{-1} \mathrm{~s}^{-1}, 30 \mathrm{~min}$ illumination.

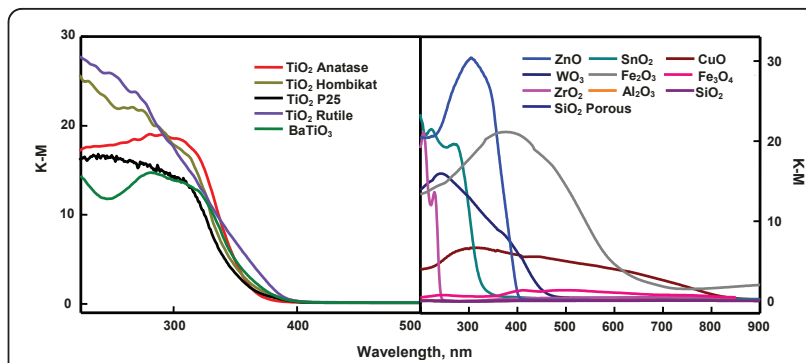

Figure 3 DRS of the oxides.

insulators and hence do not absorb in the visible and UVA region.

\subsection{Photocatalytic oxidation of iodide}

In aqueous suspension, anatase $\mathrm{TiO}_{2}$ catalyzes iodide ion oxidation more effectively whereas Hombikat $\mathrm{TiO}_{2}$ and $\mathrm{TiO}_{2} \mathrm{P} 25$ effectively, $\mathrm{Al}_{2} \mathrm{O}_{3}, \mathrm{SiO}_{2}, \mathrm{BaTiO}_{3}$, and $\mathrm{ZnO}$ moderately and $\mathrm{ZrO}_{2}$, rutile $\mathrm{TiO}_{2}, \mathrm{SnO}_{2}, \mathrm{WO}_{3}, \mathrm{CuO}$, $\mathrm{Fe}_{2} \mathrm{O}_{3}$, and $\mathrm{Fe}_{3} \mathrm{O}_{4}$ feebly under UVA light. The UV-visible spectrum of KI solution illuminated with any of the said oxides reveals iodine formation $\left(\lambda_{\max } 350 \mathrm{~nm}\right)$; the spectra are akin to that of the authentic iodine-iodide solution (not given). Chemical tests also confirm the formation of iodine; the solution turns purple with starch and discharged by thiosulfate. The iodine liberation does not occur in dark. Also, the photogeneration of iodine in absence of the oxides is insignificant (data not presented).

Figure 4 is the time profile of photoformation of iodine. It shows that iodine-generation on $\mathrm{TiO}_{2}$ anatase, $\mathrm{TiO}_{2}$ Hombikat and $\mathrm{TiO}_{2}$ P25 slackens in $15 \mathrm{~min}$ whereas that on $\mathrm{ZnO}$ and $\mathrm{WO}_{3}$ does so at 30 and 60 min, respectively. The other oxides exhibit sustainable photocatalysis at least up to $2 \mathrm{~h}$ of illumination. The slackening of iodine-formation with illumination time is not unknown. Photoformation of iodine on $\mathrm{Ag}-\mathrm{TiO}_{2}$ [7], Pt- $\mathrm{TiO}_{2}$ [10], phthalocyanine sensitized $\mathrm{TiO}_{2}$ [11] and immobilized $\mathrm{TiO}_{2}[5]$ or $\mathrm{ZnO}[5,6]$ show such behavior. Since the iodine generation on $\mathrm{TiO}_{2}$ anatase, $\mathrm{TiO}_{2}$ Hombikat and $\mathrm{TiO}_{2}$ P25 are not slackened at least up to $15 \mathrm{~min}$ and on the other oxides at least up to $30 \mathrm{~min}$, the reaction rates have been obtained by measuring the iodine formed in 15 and $30 \mathrm{~min}$ on anatase, Hombikat and $\mathrm{P} 25 \mathrm{TiO}_{2}$ and the rest of the oxides, respectively. All the nanooxides show sustainable photocatalysis. The recycled oxides without any pre-treatment provide identical results (results not listed). Figure 4 also displays the iodine-formation rate at different concentrations of iodide ion. $\mathrm{SnO}_{2}, \mathrm{WO}_{3}, \mathrm{CuO}, \mathrm{Fe}_{2} \mathrm{O}_{3}, \mathrm{Fe}_{3} \mathrm{O}_{4}, \mathrm{ZrO}_{2}$ and $\mathrm{SiO}_{2}$ show linear increase of reaction rate with $\left[\mathrm{I}^{-}\right]$indicating first-order kinetics. The other oxides exhibit saturation kinetics revealing Langmuir-Hinshelwood 


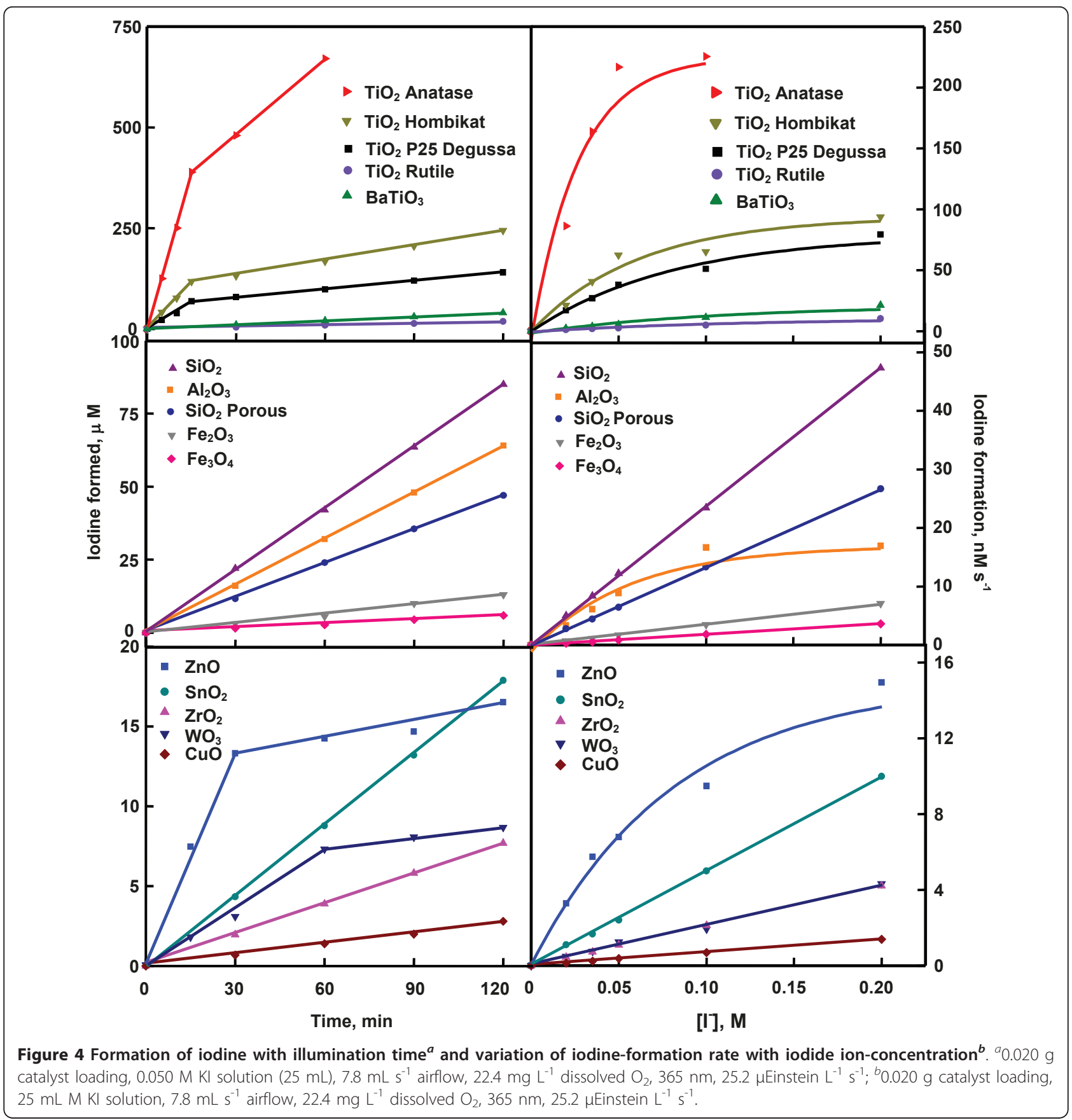

kinetic model $[4,7]$. The generation of iodine at different airflow rates is displayed in Figure 5. Iodine-formation is enhanced with increased airflow and the variation conforms to Langmuir-Hinshelwood kinetics. Moreover, oxygen is essential for the photoformation of iodine. Iodine is not formed in nitrogen-purged iodide ion solution illuminated with any of the studied oxide (data not listed). The dependence of generation of iodine on the light intensity is also displayed in Figure 5. The photocatalysis lacks linear dependence on photon flux. Less than first power dependence of rates of surface-photocatalyzed reactions on light intensity at high photon flux is known $[4,7]$. The dependence of photocatalytic iodine generation on the $\mathrm{pH}$ of the medium is shown in Figure 6. The $\mathrm{pH}$ of the slurry was adjusted by the addition of small volume of $\mathrm{NaOH}$ or $\mathrm{HCl}$ solution. Except $\mathrm{TiO}_{2}$ rutile and $\mathrm{BaTiO}_{3}$ all other oxides slow down the iodine generation with increase of $\mathrm{pH}$. Rutile $\mathrm{TiO}_{2}$ and $\mathrm{BaTiO}_{3}$ are less sensitive to $\mathrm{pH}$ variation. The adsorption of ionic species on the semiconductor depends also on the 


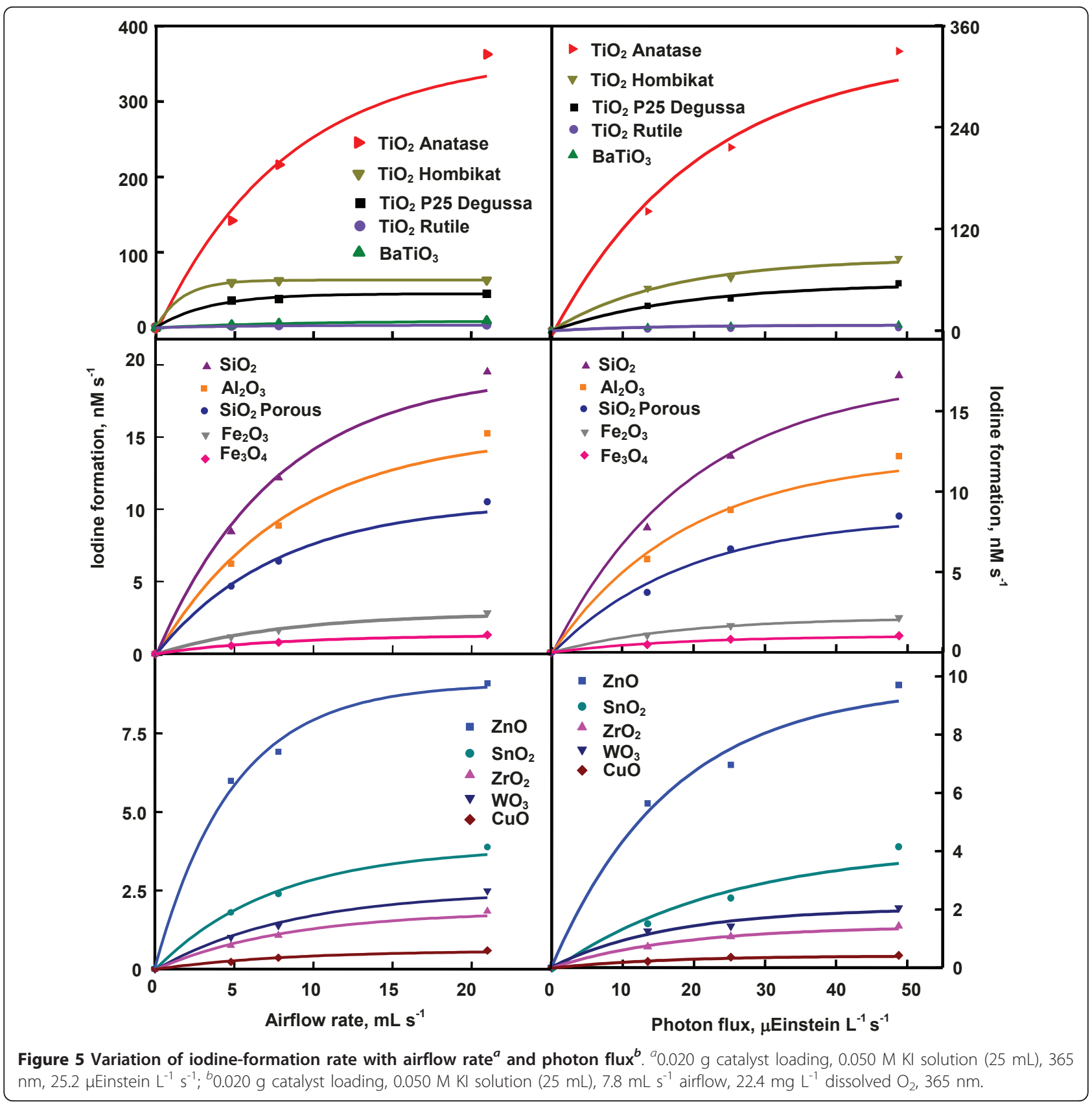

surface excess charge on the semiconductor crystals. At $\mathrm{pH}$ higher than the point of zero charge (PZC), the semiconductor surface is negatively charged resulting in electrostatic repulsion between iodide ion and the semiconductor crystal. Hence, the concentration of iodide ion at the surface and in the double layer is likely to be lesser than that in the bulk of the solution. The adsorption isotherm turns linear leading to a first order kinetics of photocatalysis. The PZC for $\mathrm{TiO}_{2}, \mathrm{BaTiO}_{3}$, $\mathrm{SnO}_{2}, \mathrm{ZnO}, \mathrm{WO}_{3}, \mathrm{CuO}, \mathrm{Fe}_{2} \mathrm{O}_{3}, \mathrm{Fe}_{3} \mathrm{O}_{4}$, and $\mathrm{ZrO}_{2}$ are $5.8,9.0,4.3,8.8,0.4,9.5,8.6,6.5$ and 6.7 , respectively
[9]. Examination of Figure 6 reveals, for some oxides at least $\left(\mathrm{TiO}_{2}, \mathrm{SnO}_{2}, \mathrm{Fe}_{2} \mathrm{O}_{3}, \mathrm{Fe}_{3} \mathrm{O}_{4}\right.$ and $\left.\mathrm{ZrO}_{2}\right)$, uniform trend in the photocatalysis at $\mathrm{pH}$ higher as well as lower than the PZC. A possible explanation is the modification of the PZC values by the ions present in the solution $[12,13]$. For example, the $\mathrm{PZC}$ of $\mathrm{TiO}_{2}$ is reported to change from 6.4 to 4.5 [12]. Hence it is possible that the PZC values of $\mathrm{TiO}_{2}, \mathrm{SnO}_{2}, \mathrm{Fe}_{2} \mathrm{O}_{3}, \mathrm{Fe}_{3} \mathrm{O}_{4}$ and $\mathrm{ZrO}_{2}$ in the slurry fall outside the range of measured $\mathrm{pH}$. The catalyzed oxidation of iodide ion carried out separately with light of wavelength 254 and $365 \mathrm{~nm}$ reveals that 


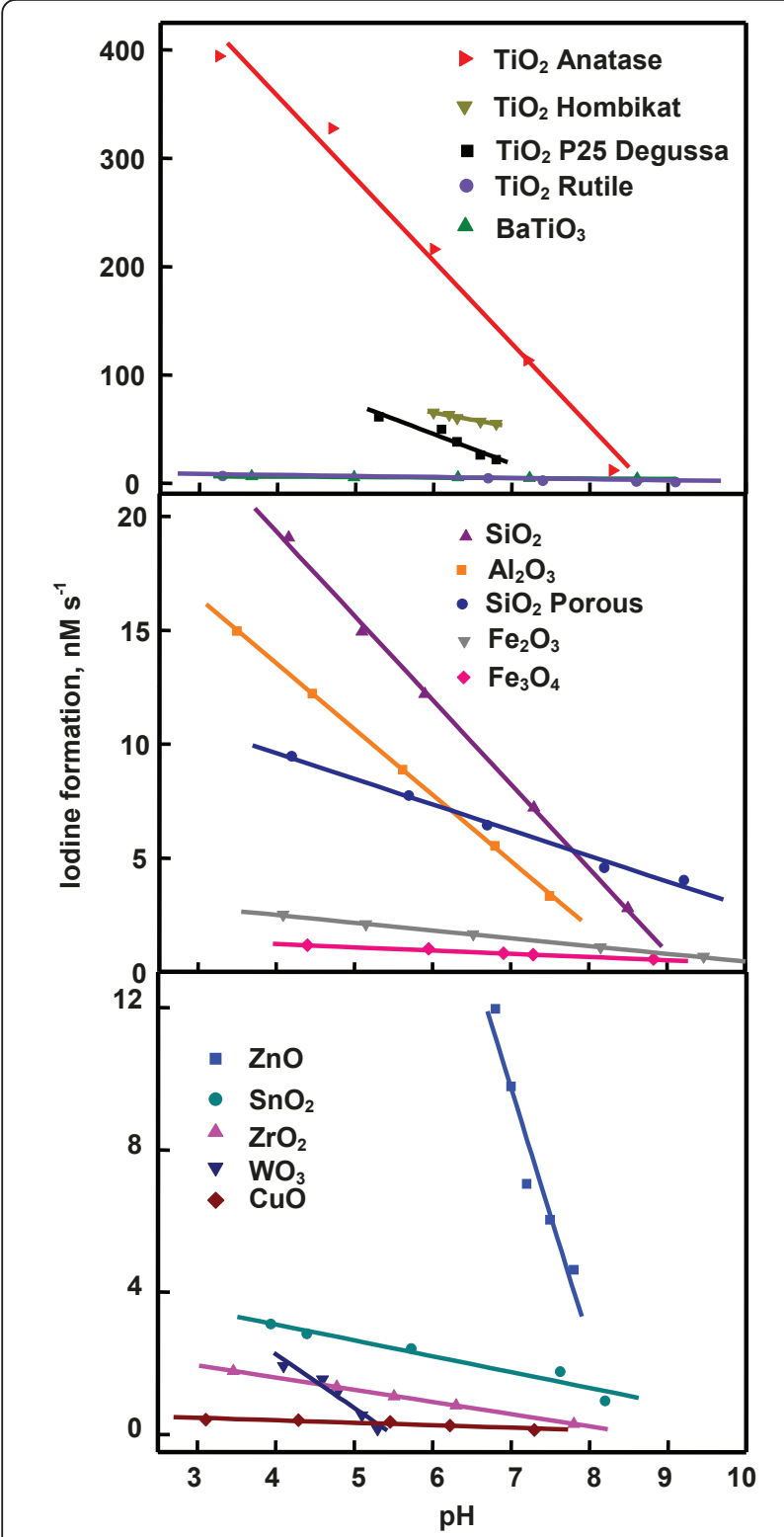

Figure 6 Dependence of iodine-formation rate on pH. $0.020 \mathrm{~g}$ catalyst loading, $0.050 \mathrm{M} \mathrm{Kl}$ solution $(25 \mathrm{~mL}), 7.8 \mathrm{~mL} \mathrm{~s}^{-1}$ airflow, 22.4 $\mathrm{mg} \mathrm{L}^{-1}$ dissolved $\mathrm{O}_{2}, 365 \mathrm{~nm}, 25.2 \mu$ Einstein $\mathrm{L}^{-1} \mathrm{~s}^{-1}$.

UVC light is more effective than UVA light to generate iodine (Table 2). A possible reason for the larger formation of iodine under UVC radiation than UVA radiation is that the generated iodine also absorbs at $365 \mathrm{~nm}$. That is, the liberated iodine may act as an inner filter by absorbing part of the UVA illumination thereby decreasing the intensity of impinging radiation on the nanoparticles. In the case of $\mathrm{ZrO}_{2}, 254 \mathrm{~nm}$-illumination will bring in band gap excitation. This may lead to the larger iodine-formation. Table 2 also shows that with majority of oxides studied the photogeneration of iodine is more in the immersion reactor than in the tubular reactor. $\mathrm{BaTiO}_{3}, \mathrm{CuO}, \mathrm{Fe}_{3} \mathrm{O}_{4}, \mathrm{ZrO}_{2}$ and $\mathrm{SiO}_{2}$ porous are the exceptions. These oxides fail to disperse uniformly throughout the volume of the KI solution $(250 \mathrm{~mL})$ in the immersion reactor. It is evident from Table 2 that baring the said five oxides the process is not limited to micro-level.

Comparison of the photocatalytic efficiencies of the nanomaterials reveals $\mathrm{TiO}_{2}$ anatase as the most efficient photocatalyst. Even the benchmark photocatalyst $\mathrm{TiO}_{2}$ P25 Degussa, which is a blend of anatase and rutile, is found to be less effective than the anatase studied. $\mathrm{TiO}_{2}$ rutile shows poor photocatalytic activity. Many semiconductors such as $\mathrm{BaTiO}_{3}, \mathrm{SnO}_{2}, \mathrm{ZnO}, \mathrm{WO}_{3}, \mathrm{CuO}$ and $\mathrm{Fe}_{2} \mathrm{O}_{3}$ fail to display better photocatalytic efficiency than the insulators $\mathrm{Al}_{2} \mathrm{O}_{3}$ and $\mathrm{SiO}_{2}$. One of the possible reasons is the unabated rapid recombination of the photogenerated electron-hole pairs in these semiconductors. Another reason could be the large surface area of $\mathrm{SiO}_{2}$. The mechanism of photocatalytic oxidation of iodide ion and also that of iodide ion-photooxidation on $\mathrm{Al}_{2} \mathrm{O}_{3}$ and $\mathrm{SiO}_{2}$ surfaces have been discussed elsewhere in detail $[4-6,8]$.

Improving the photocatalytic efficiency, particularly that of generation of energy bearing chemicals via thermodynamically uphill reactions, is of prime concern in solar energy conversion and storage. The listed oxides show improved photoformation of iodine in acetonitrile and Table 1 displays the results. Among the effective semiconductors, on moving from aqueous to acetonitrile medium the photocatalysis by $\mathrm{TiO}_{2}$ anatase improves by about $65 \%$ whereas those by $\mathrm{TiO}_{2}$ P25 and Hombikat increases by about 6- and 4-folds, respectively. On switching from aqueous to acetonitrile medium, among moderates catalysis, $\mathrm{ZnO}$ improves its efficiency by about 13-fold whereas $\mathrm{BaTiO}_{3}, \mathrm{Al}_{2} \mathrm{O}_{3}$ and $\mathrm{SiO}_{2}$ could do so only by about 4 -fold. Among the feebly active catalyst, the least active $\mathrm{CuO}$ and $\mathrm{Fe}_{3} \mathrm{O}_{4}$ improve their efficiencies in acetonitrile by about 55 and $25 \%$, respectively. Rutile $\mathrm{TiO}_{2}$ and $\mathrm{SnO}_{2}$ efficiencies go up by 8-fold, whereas that of $\mathrm{ZrO}_{2}$ and $\mathrm{Fe}_{2} \mathrm{O}_{3}$ is by about $15 \%$. However, $\mathrm{WO}_{3}$ efficiency is increased by about $35 \%$. General analysis of Table 1 shows that the efficiencies of the less active catalysts are improved many fold on using acetonitrile as medium instead of water. A possible reason for the larger photocatalytic activity in acetonitrile is the absence of hole-capture by hydroxyl ion and water molecule. One of the plausible explanations for the enhanced formation of iodine in acetonitrile on insulator surface may be the efficient transfer of excited electron from the adsorbed iodide ion to the neighboring adsorbed oxygen molecule. In aqueous suspension, adsorption of water molecule and hydroxide ion on the insulator surface may reduce the probability of adjacent 
Table 2 lodide-oxidation at different wavelength of illumination and in tubular and immersion reactors*

\begin{tabular}{|c|c|c|c|c|}
\hline Oxide & lodine-formation $\left(\mathrm{nM} \mathrm{s}^{-1}\right)$ & & lodine-formed $(\mu \mathrm{M})$ & \\
\hline & 254 nm-illumination ${ }^{a}$ & $365 \mathrm{~nm}$ - illumination ${ }^{b}$ & Tubular reactor $^{c}$ & Immersion reactor $^{d}$ \\
\hline $\mathrm{TiO}_{2}$ (anatase) & 298 & 170 & 9.7 & 58 \\
\hline $\mathrm{TiO}_{2}$ P25 & 46 & 45 & 1.8 & 20 \\
\hline $\mathrm{TiO}_{2}$ Hombikat & 56 & 49 & 2.8 & 5.4 \\
\hline $\mathrm{TiO}_{2}$ (rutile) & 22 & 2.2 & 0.11 & 0.55 \\
\hline $\mathrm{BaTiO}_{3}$ & 38 & 2.8 & 0.24 & 0.03 \\
\hline $\mathrm{ZnO}$ & 25 & 6.3 & 0.31 & 0.90 \\
\hline $\mathrm{SnO}_{2}$ & 21 & 1.8 & 0.11 & 0.28 \\
\hline $\mathrm{WO}_{3}$ & 30 & 0.9 & 0.07 & 0.17 \\
\hline $\mathrm{CuO}$ & 24 & 0.3 & 0.02 & 0.01 \\
\hline $\mathrm{Fe}_{2} \mathrm{O}_{3}$ & 27 & 1.3 & 0.08 & 0.30 \\
\hline $\mathrm{Fe}_{3} \mathrm{O}_{4}$ & 25 & 0.5 & 0.04 & 0.01 \\
\hline $\mathrm{ZrO}_{2}$ & 21 & 0.6 & 0.05 & 0.02 \\
\hline $\mathrm{Al}_{2} \mathrm{O}_{3}$ & 34 & 6.8 & 0.40 & 1.1 \\
\hline $\mathrm{SiO}_{2}$ & 43 & 6.8 & 0.55 & 1.8 \\
\hline $\mathrm{SiO}_{2}$ (porous) & 27 & 5.9 & 0.29 & 0.18 \\
\hline
\end{tabular}

${ }^{*} 0.020 \mathrm{~g}$ oxide loading, $0.050 \mathrm{M}$ iodide, $7.8 \mathrm{~mL} \mathrm{~s}^{-1}$ airflow, $22.4 \mathrm{mg} \mathrm{L}^{-1}$ dissolved $\mathrm{O}_{2}, 30$ min illumination.

${ }^{a} 6.2 \mu$ Einstein $\mathrm{L}^{-1} \mathrm{~s}^{-1}, 10 \mathrm{~mL}$ iodide solution.

${ }^{b} 18.4 \mu$ Einstein $\mathrm{L}^{-1} \mathrm{~s}^{-1}, 10 \mathrm{~mL}$ iodide solution.

${ }^{{ }^{6}} 365 \mathrm{~nm}, 25.2 \mu$ Einstein $\mathrm{L}^{-1} \mathrm{~s}^{-1}, 25 \mathrm{~mL}$ iodide solution.

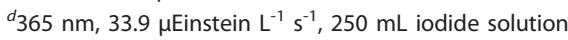

adsorption of iodide ion and oxygen molecule. The photocatalytic efficiencies of the nanoparticles are of the order: $\mathrm{TiO}_{2}$ anatase $>\mathrm{TiO}_{2} \mathrm{P} 25 \approx \mathrm{TiO}_{2}$ Hombikat $>$ $\mathrm{ZnO}>\mathrm{WO}_{3}>\mathrm{Al}_{2} \mathrm{O}_{3} \approx \mathrm{SiO}_{2} \approx \mathrm{SnO}_{2} \approx \mathrm{BaTiO}_{3} \approx \mathrm{CuO}$ $\approx \mathrm{Fe}_{2} \mathrm{O}_{3} \approx \mathrm{Fe}_{3} \mathrm{O}_{4} \approx \mathrm{ZrO}_{2}$. These efficiencies are not in accordance with their band gap energies.

\section{Conclusions}

The photocatalytic efficiency of anatase $\mathrm{TiO}_{2}$ to generate iodine is much larger than those of $\mathrm{TiO}_{2} \mathrm{P} 25, \mathrm{TiO}_{2}$ Hombikat, $\mathrm{TiO}_{2}$ rutile, $\mathrm{BaTiO}_{3}, \mathrm{ZnO}, \mathrm{SnO}_{2}, \mathrm{WO}_{3}, \mathrm{CuO}$, $\mathrm{Fe}_{2} \mathrm{O}_{3}, \mathrm{Fe}_{3} \mathrm{O}_{4}, \mathrm{ZrO}_{2}, \mathrm{Al}_{2} \mathrm{O}_{3}$ and $\mathrm{SiO}_{2}$ nanoparticles. Some of the studied nanocrystalline semiconductors are less efficient than $\mathrm{Al}_{2} \mathrm{O}_{3}$ and $\mathrm{SiO}_{2}$ nanoparticles. The photocatalysis conforms to the Langmuir-Hinshelwood kinetic model. Use of acetonitrile as medium favors the photogeneration of iodine.

\section{Experimental}

\subsection{Materials}

$\mathrm{TiO}_{2}$ anatase, $\mathrm{TiO}_{2}$ rutile, $\mathrm{ZnO}, \mathrm{SnO}_{2}, \mathrm{WO}_{3}, \mathrm{CuO}$, $\mathrm{Fe}_{2} \mathrm{O}_{3}, \mathrm{Fe}_{3} \mathrm{O}_{4}, \mathrm{ZrO}_{2}, \mathrm{BaTiO}_{3}, \mathrm{Al}_{2} \mathrm{O}_{3}$ and $\mathrm{SiO}_{2}$ nanopowders used were those supplied by Sigma Aldrich. $\mathrm{TiO}_{2}$ Hombikat was supplied by Fluka. $\mathrm{TiO}_{2} \mathrm{P} 25$ was a gift from Degussa.

\subsection{Characterization}

The powder X-ray diffractograms were recorded with a Bruker D8 system using $\mathrm{Cu} \mathrm{K \alpha}$ radiation of wavelength $1.5406 \AA$ in a $2 \theta$ range of $10-70^{\circ}$ at a scan rate of $0.05^{\circ}$ $\mathrm{s}^{-1}$ with a tube current of $30 \mathrm{~mA}$ at $40 \mathrm{kV}$. Rich. Siefert model $3000 \mathrm{X}$-ray diffractrometer was also employed to obtain the diffraction pattern. A PerkinElmer Lambda 35 or Varian-Cary 5E or Shimadzu UV-2450 spectrophotometer was used to record the UV-visible diffuse reflectance spectra (DRS) of the oxides.

\subsection{Photoreactors}

A photoreactor fitted with eight 8-W mercury lamps of wavelength $365 \mathrm{~nm}$ (Sankyo Denki, Japan) and highly polished aluminum reflector was used for the detailed photocatalytic study. The reactor was cooled by fans mounted at the bottom. Borosilicate glass tube of 15$\mathrm{mm}$ inner diameter was employed as the reaction vessel. Immersion type photoreactor with $125-\mathrm{W}$ medium pressure mercury lamp emitting at $365 \mathrm{~nm}$, surrounded by highly polished anodized aluminum reflector, was also used. The reaction vessel was a $500-\mathrm{mL}$ double walled borosilicate immersion well with inlet and outlet for water circulation. Micro photoreactor with $6-\mathrm{W}, 254-$ $\mathrm{nm}$ low pressure mercury lamp and 6-W, 365-nm medium pressure mercury lamp was employed to study photocatalysis under UVC and UVA light.

\subsection{Photocatalytic study}

KI-solutions of required concentrations were prepared afresh and used. The volume of solution employed in multilamp, immersion and micro photoreactors were 25 , 250 and $10 \mathrm{~mL}$, respectively. Air was bubbled through the reaction solution using a micro air pump which 
kept the added nanoparticles under suspension and at constant motion. The airflow rate was determined by soap bubble method, the dissolved oxygen was measured using Elico dissolved oxygen analyzer PE 135 and the light intensity was found out by ferrioxalate actinometry.

\section{Acknowledgements}

Financial support through research grant no. F.12-64/2003 (SR) by the University Grants Commission (UGC), New Delhi, is thankfully acknowledged. P.A. is grateful to UGC for PF and PG to CSIR for SRF.

\section{Authors' contributions}

This work was made by CK's research group. This project was based on the ideas of CK and carried out under his guidance and consultation. PA carried out most of the experimental work and PG was involved in XRD analysis and preparation of the manuscript. All authors read and approved the final manuscript.

\section{Competing interests}

The authors declare that they have no competing interests.

Received: 11 May 2011 Accepted: 16 June 2011 Published: 16 June 2011

\section{References}

1. Hu X, Li G, Yu JC: Design, fabrication, and modification of nanostructured semiconductor materials for environmental and energy applications. Langmuir 2010, 26:3031-3039.

2. Gaya UI, Abdullah AH: Heterogeneous photocatalytic degradation of organic contaminants over titanium dioxide: a review of fundamentals, progress and problems. J Photochem Photobiol C 2008, 9:1-12.

3. Xiang $\mathrm{O}, \mathrm{Yu}$ J, Wong PK: Quantitative characterization of hydroxyl radicals produced by various photocatalysts. J Colloid Interface Sci 2011, 357:163-167.

4. Karunakaran C, Senthilvelan S, Karuthapandian S, Balaraman K: Photooxidation of iodide ion on some semiconductor and nonsemiconductor surfaces. Catal Com 2004, 5:283-290.

5. Karunakaran C, Anilkumar P: Semiconductor-catalyzed solar photooxidation of iodide ion. J Mol Catal A 2007, 265:153-158.

6. Karunakaran C, Anilkumar P: Photooxidation of iodide ion on immobilized semiconductor powders. Sol Energy Mater Sol Cells 2008, 92:490-494.

7. Karunakaran $\mathrm{C}$, Anilkumar $\mathrm{P}$, Gomathisankar P: Kinetics of $\mathrm{Ag}_{-}-\mathrm{TiO}_{2}-$ photocatalyzed iodide ion oxidation. Monatsh Chem 2010, 141:529-537.

8. Karunakaran C, Dhanalakshmi R, Manikandan G, Gomathisankar P: Photodegradation of carboxylic acids on $\mathrm{Al}_{2} \mathrm{O}_{3}$ and $\mathrm{SiO}_{2}$ nanoparticles. Indian J Chem 2011, , 50A: 163-170.

9. Xu Y, Schoonen MAA: The absolute energy position of conduction and valence bands of selected semiconducting minerals. Am Mineral 2000, 85:543-556.

10. Ohno T, Fujihara K, Saito S, Matsumura M: Forwarding reversible phoocatalytic reactions on semiconductor particles using an oil/water boundary. Sol Energy Mater Sol Cells 1997, 45:169-174.

11. Hodak J, Quinteros C, Litter MI, Roman ES: Sensitization of $\mathrm{TiO}_{2}$ with phthalocyanines Part 1.-Photooxidations using hydroxoaluminium tricarboxymonoamidephthalocyanine adsorbed on $\mathrm{TiO}_{2}$. J Chem Soc Faraday Trans 1996, 92:5081-5088.

12. Gimenez J, Aguado MA, Cervera-March S: Photocatalytic reduction of chromium(VI) with titania powders in a flow system. Kinetics and catalyst activity. J Mol Catal A 1996, 105:67-78.

13. Domenech J, Munoz J: Photocatalytical reduction of $\mathrm{Cr}(\mathrm{VI})$ over $\mathrm{ZnO}$ powder. Electrochim Acta 1987, 32:1383-1386.

doi:10.1186/1752-153X-5-31

Cite this article as: Karunakaran et al.: Photoproduction of iodine with nanoparticulate semiconductors and insulators. Chemistry Central Journal 2011 5:31.

\section{Publish with ChemistryCentral and every scientist can read your work free of charge \\ "Open access provides opportunities to our colleagues in other parts of the globe, by allowing anyone to view the content free of charge." W. Jeffery Hurst, The Hershey Company. \\ - available free of charge to the entire scientific community - peer reviewed and published immediately upon acceptance \\ - cited in PubMed and archived on PubMed Central \\ - yours - you keep the copyright \\ Submit your manuscript here: \\ http://www.chemistrycentral.com/manuscript/<smiles>c1ccccc1</smiles> ChemistryCentral}

